\title{
A Comparison of Numbers of Taxa in the Recent Mammalian Fauna of the Old and New Worlds
}

\author{
Adam KRZANOWSKI
}

\begin{abstract}
Krzanowski A., 1986: A comparison of numbers of taxa in the recent mammalian fauna of the Old and New Worlds. Acta theriol., 31, 16: 207-220 [With 10 Tables].

A work by Honacki et al. (1982) has been used as a basis for comparisons of ratios between number of genera/number of families $(G / F)$, species/genera (S/G), and also, although to a lesser extent, the ratios between number of families/number of orders (F/O), and species/ families (S/F) made for mammals of the World. 11 orders of mammals having their representatives in both parts of the World have been considered. The endemic taxa occurring in either of these two regions, and the taxa common to both regions have been distinguished. Generally, in all mammals, the $S / G$ ratio is markedly lower than the G/F and F/O ratios. Particularly high proportion of common taxa has been found among marine orders and also among carnivores (even after exclusion of Pinnipedia). High ratios have been noted mostly among orders that are numerous and include mammals of small body size. Low ratios have been found among marine orders whose members have large body size. Bats do not differ in ratios from other small mammals. There are striking differences in the $S / F$ ratio between America and the Old World. The differences attain the highest values among Insectivora while only small ones are noted among Primates. The highest values of $S / F$ proportions for the whole World appear among Insectivora, Chiroptera, and Rodentia, whereas Sirenia, Perissodactyla, and Cetacea represent orders with the lowest ratios. In general, the families in the Old World are richer in species than their American counterparts. The Old World, with its enormous fragmentation has relatively low number of mammalian species; especially Rodentia are few. In other words, America is very rich in mammals, particularly in rodents.

[Inst. System. Exper. Zool., PAS, Sławkowska 17, 31-016 Kraków, Poland]
\end{abstract}

\section{INTRODUCTION}

The immediate aim of this study was to establish and compare ratios: between various taxa of mammals and between those living in the Old and New Worlds. Additional interest has been attached to possible differences in these ratios between bats and other mammals. There was also a more distant goal i.e. a search for the new rules and tendencies that could be assessed on the basis of these comparisons. 


\section{METHOD}

The study concerned chiefly these mammalian orders that are common to the Old World and America. In such orders the following ratios have been studied: number of genera/number of families (later denoted $\mathrm{G} / \mathrm{F})$, species/genera $(\mathrm{S} / \mathrm{G})$, and to a lesser extent the ratios between number of families/number of orders $(\mathrm{F} / \mathrm{O})$, and species/families $(\mathrm{S} / \mathrm{F})$. Stating that a taxon occur in the Old (New) World means that it inhabits only this particular region i.e. is endemic. On the other hand "common" taxa are those which occur in both parts of the World. A work by Honacki et al. (1982) has been used as a basis for comparisons, with addition of several American taxa of Insectivora and Rodentia that have become extinct not very long ago according to Hall (1981).

\section{RESULTS AND DISCUSSION}

The results are presented in Tables 1 to 10 .

Out of 20 orders of mammals 1 inhabits the New World (Edentata), 8 - the Old World (Monotremata, Scandentia, Dermoptera, Proboscidea, Hyracoidea, Tubulidentata, Pholidota, Macroscelidea), the remaining 11 orders are common to both parts of the World.

Out of 139 families, 37 occur in the New World, 66 - in the Old World, and 36 are common. Among the last group 14 families represent mainly marine mammals belonging to Carnivora (3), Cetacea (9), and Sirenia (2).

The list of genera given by Honacki et al. (1982) has been supplemented with three taxa that become extinct not a long time ago (Hall 1981): +Nesophontes (Insectivora: +Nesophontidae), +Elasmodontomys and +Quemisia (Rodentia: +Heptaxodontidae) bringing the total number of genera to 1037. The inclusion of these extinct taxa complies with the results of recent research (Kennedy, 1975) suggesting that man colonized America much earlier than it was once thought (Darlington, 1957, p. 632). This entails possibility that man might have played a role in the extinction of these taxa. Out of 1037 genera, 308 lives in the New World, 641 - in the Old World, and 88 are common.

On the same basis as mentioned earlier, the number of species has been augmented by six species of the genus +Nesophontes and by one species each of the genera +Elasmodontomys and +Quemisia. From the resulting number of 4179 species 1419 inhabits the New World, 2663 - the Old World, and 97 species are common. Results are given in Tables 1 and 2 .

Orders that are endemic to either part constitute $45 \%$ of the total 


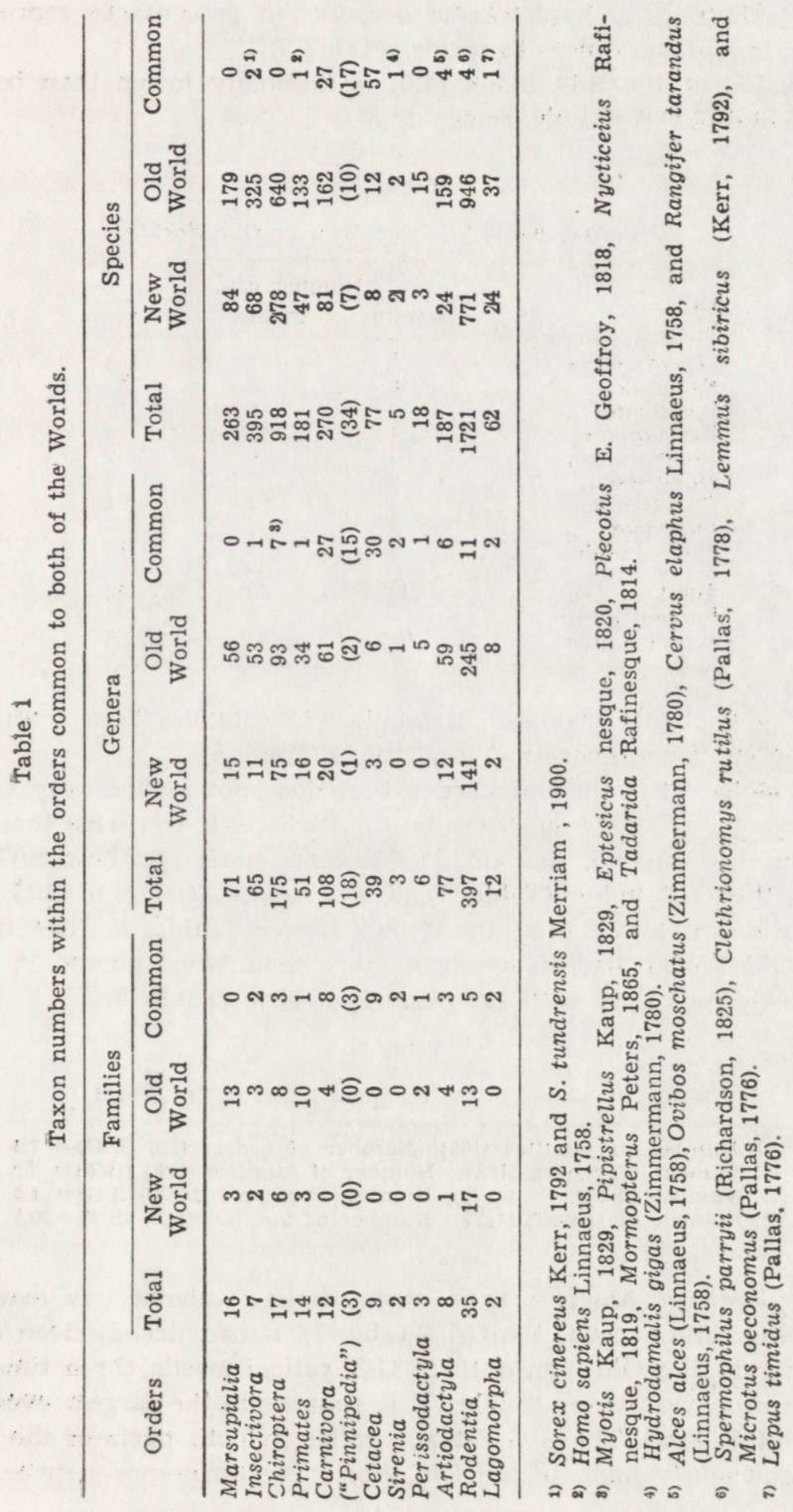


number. There is a characteristic decrease in percentages representing endemic taxa, from orders to species (Table 2).

The value of the S/G index (4.0) is markedly lower than both the $\mathrm{F} / 0(7.0)$ and $\mathrm{G} / \mathrm{F}$ (7.5) indexes (Table 3).

Table 2

Orders endemic to either New or Old World.

\begin{tabular}{lcrr}
\hline & \multicolumn{3}{c}{ Number of: } \\
\cline { 2 - 4 } Order & families & genera & species \\
\hline Monotremata & 2 & 3 & 3 \\
Edentata & 5 & 13 & 29 \\
Scandentia & 1 & 5 & 16 \\
Dermaptera & 1 & 1 & 2 \\
Proboscidea & 1 & 2 & 2 \\
Hyracoidea & 1 & 3 & 7 \\
Tubulidentata & 1 & 1 & 1 \\
Pholidota & 1 & 1 & 7 \\
Macroscelidea & 1 & 4 & 15 \\
Total & 14 & 33 & 82 \\
Percentage of & 10.1 & 3.2 & 2.0 \\
World fauna & & & \\
\hline
\end{tabular}

Rapid and steady decrease in number of common taxa from orders to species confirms theoretical predictions (Table 5).

Marsupialia: It is the only order that does not include any common taxa among the higher ones (Table 6). Perhaps it confirms their early radiation. In America, marsupials show an anomaly: their $S / G$ index exceeds the $\mathrm{G} / \mathrm{F}$ index (Table 7 ). The indexes $\mathrm{G} / \mathrm{F}$ and $\mathrm{S} / \mathrm{G}$ in the Old World are lower than those in America (Table 7). The families of the Old World are, on average, more than twice poorer at species level when compared with the American ones (Table 8).

Table 3

Ratios of taxons in the mammal fauna of the World.

I. Number of families (139): Number of orders $(20)(F / O)=7.0$

II. Number of genera (1037): Number of families (139) $(\mathrm{G} / \mathrm{F})=7.5$

III. Number of species (4179): Number of genera $(1037)(\mathrm{S} / \mathrm{G})=4.0$

IV. Number of species (4179): Number of families (139) $(S / F)=30.1$

Insectivora: In America they show similar anomaly as marsupials ie. the $\mathrm{S} / \mathrm{G}$ ratio exceeds the $\mathrm{G} / \mathrm{F}$ (Table 7 ). It has already been emphasized that in the Old World their G/F ratio exceeds three times that in American insectivores (Table 7). It represents the largest ever difference of this kind. The S/G ratios, similar in both parts of the World, are conspicuously high, in the Old World the difference between these 
Table 4

Ratios of taxons in the New and in the Old World (taxons common to both of the Worlds included).

\begin{tabular}{|c|c|c|c|c|}
\hline \multicolumn{3}{|c|}{ New World } & \multicolumn{2}{|c|}{ Old World } \\
\hline \multirow{2}{*}{ I. } & Number of families & (73) & Number of families & (102) \\
\hline & Number of orders & $(12)=$ & Number of orders & $(19)=$ \\
\hline \multirow{2}{*}{ II. } & Number of genera & $(396)$ & Number of genera & (729) \\
\hline & Number of families & (73) & Number of families & (102) \\
\hline \multirow{2}{*}{ III. } & Number of species & (1516) & Number of species & $(2760)=$ \\
\hline & Number of genera & $(396)$ & Number of genera & (729) \\
\hline \multirow{2}{*}{ IV. } & Number of species & (1516) $=$ & Number of species & $(2760)$ \\
\hline & Number of families & (73) & Number of families & (102) \\
\hline
\end{tabular}

Table 5

Numbers of taxons common to both parts of the World (Total numbers of taxons are given in parentheses).

\begin{tabular}{cc}
\hline Number of taxons & $\begin{array}{c}\text { Percentage } \\
\text { of the World fauna }\end{array}$ \\
\hline \multicolumn{3}{c}{ The whole of fauna } \\
Orders: $11(20)$ & 55.5 \\
Families: $36(139)$ & 25.9 \\
Genera: $88(1037)$ & 8.5 \\
Species: $97(4179)$ & 2.3 \\
"Pinnipedia", Cetacea, and Sirenia excluded: \\
Orders: $9(18)$ & 50.0 \\
Families: $22(125)$ & 17.6 \\
Genera: $28(977)$ & 2.9 \\
Species: $22(4063)$ & 0.5 \\
\hline
\end{tabular}

Table 6

Percentages of taxons common to both parts of the World with regard to particular orders. (Numbers of taxons common vs. all the ones are given in parentheses).

\begin{tabular}{lccc}
\hline & Families & Genera & Species \\
\hline Marsupialia & $0.0 \%(0: 16)$ & $0.0 \%(0: 71)$ & $0.0 \%(0: 263)$ \\
Insectivora & $28.7 \%(2: 7)$ & $1.5 \%(1: 65)$ & $0.5 \%(2: 395)$ \\
Chiroptera & $17.6 \%(3: 17)$ & $4.0 \%(7: 175)$ & $0.0 \%(0: 918)$ \\
Primates & $7.1 \%(1: 14)$ & $2.0 \%(1: 51)$ & $0.6 \%(1: 181)$ \\
Carnivora & $66.7 \%(8: 12)$ & $25.0 \%(27: 108)$ & $10.0 \%(27: 270)$ \\
Carnivora & & & \\
(Pinnipedia exc1.) & $55.6 \%(5: 9)$ & $13.3 \%(12: 90)$ & $4.2 \%(10: 236)$ \\
"Pinnipedia" & $100.0 \%(3: 3)$ & $83.3 \%(15: 18)$ & $50.0 \%(17: 34)$ \\
Cetacea & $100.0 \%(9: 9)$ & $76.9 \%(30: 39)$ & $74.0 \%(57: 77)$ \\
Sirenia & $100.0 \%(2: 2)$ & $66.7 \%(2: 3)$ & $20.0 \%(1: 5)$ \\
Perissodactyla & $33.3 \%(1: 3)$ & $16.7 \%(1: 6)$ & $0.0 \%(0: 18)$ \\
Artiodactyla & $37.5 \%(3: 8)$ & $7.8 \%(6: 77)$ & $2.1 \%(4: 187)$ \\
Rodentia & $14.3 \%(5: 35)$ & $2.8 \%(11: 397)$ & $0.23 \%(4: 1721)$ \\
Lagomorpha & $100.0 \%(2: 2)$ & $16.7 \%(2: 12)$ & $1.6 \%(1: 62)$ \\
\hline
\end{tabular}




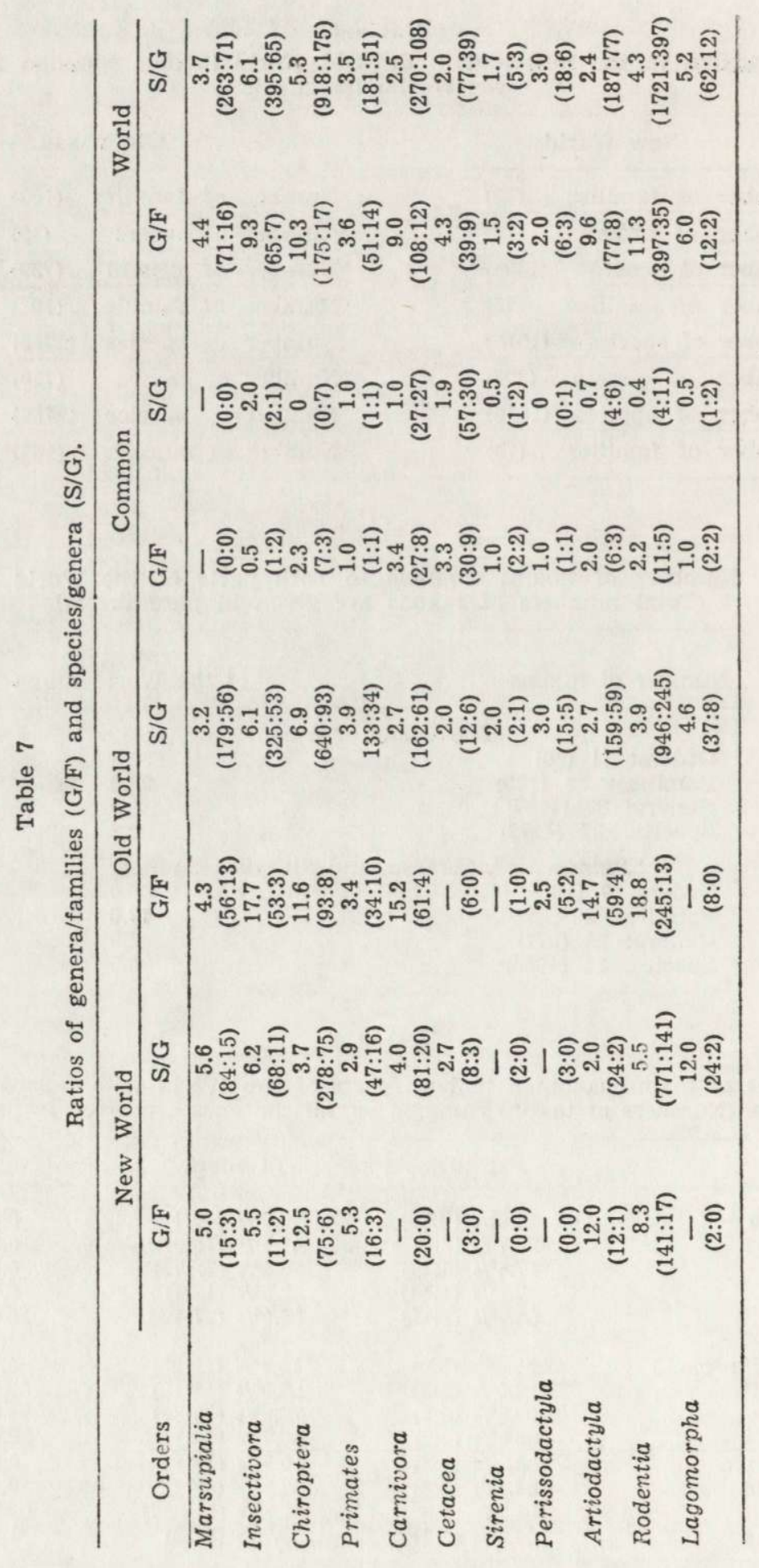


two indexes is strinkingly large (Table 7). Also in the Old World the number of species per given family is more than three times that number in America (Table 8). On a worldwide scale the families of this order are richer in species than any other mammals' family. The high percentage of common families in Insectivora is difficult to explain. It may well be a coincidence since the numbers used as a basis for calculations are relatively low. Nevertheless, the percentage exceeds twofold that in Rodentia which are better adapted to life conditions predominating in the Far North (Table 6). Perhaps Insectivora, as an older order, had more time to disperse widely. But still, the number of common genera and species of insectivores remains low.

Table 8

Proportions: number of species/number of families.

\begin{tabular}{llcr}
\hline \multicolumn{1}{c}{ Orders } & New World & Old World & World \\
\hline Marsupialia & $28.0(84: 3)$ & $13.8(179: 13)$ & $16.4(263: 16)$ \\
Insectivora & $34.0(68.2)$ & $108.3(325: 3)$ & $56.4(395: 7)$ \\
Chiroptera & $46.3(278: 6)$ & $80.0(640: 8)$ & $54.0(918: 17)$ \\
Primates & $15.7(47: 3)$ & $13.3(133: 10)$ & $12.9(181: 14)$ \\
Carnivora & $-(81: 0)$ & $40.5(162: 4)$ & $22.5(270: 12)$ \\
"Pinnipedia" & $-(7: 0)$ & $-(10: 0)$ & $11.3(34: 3)$ \\
Cetacea & $-(8: 0)$ & $-\quad(12: 0)$ & $8.6(77: 9)$ \\
Sirenia & $-(2: 0)$ & $7.5(15: 0)$ & $6.0(18: 2)$ \\
Perissodactyla & $-(3: 0)$ & $39.8(159: 4)$ & $23.4(187: 8)$ \\
Artiodactyla & $24.0(24: 1)$ & $-8(946: 13)$ & $49.2(1721: 35)$ \\
Rodentia & $45.4(771: 17)$ & $-(37: 0)$ & $31.0(62.2)$ \\
Lagomorpha & $-(24: 0)$ & &
\end{tabular}

Chiroptera: The differences between values of $\mathrm{G} / \mathrm{F}$ and $\mathrm{S} / \mathrm{G}$ ratios for American bats are significantly higher than those for the Old World ones (Table 7). A strikingly low fraction of bats among common taxa has been reflected by the fact that in work by Hopkins et al. (1982) bats do not even appear in index. In America the G/F ratio exceeds any other G/F ratio for this part of the World (Table 7). It is caused by relationships prevailing within the family Phyllostomidae which dominate in the tropics. This family includes particularly large number of genera: among 75 bat genera endemic to America as much as 47 belong to Phyllostomidae. On the other hand the S/G ratio in this part of the World remains quite low (Table 7). In the Old World, however, their G/F index is rated fifth whereas the $S / G$ index is the highest of all. Families of the Old World are much richer in species than their American counterparts while, in the whole World, the number of species per family is, by a slight margin, second only to Insectivora (Table 8). Because of their ability to fly and the early radiation (specialized forms are known from as early as Lower Eocene 
cf. Jepsen, 1966; Russell et al., 1973), Chiroptera "should" therefore have more common taxa than they actually do (Table 6). Bats, however, are principally tropical mammals (McCoy \& Connor, 1980; Wilson, 1974) that do not "feel much at home" in the Far North and hence only five species have entered the polar circle (Hall, 1981; Ryberg, 1947). The above has possibly hampered intrusion into Beringia in larger numbers. A distinctive feature to be noted here is the absence of suborder Megachiroptera in America.' It should also be noted that among common genera as many as five belong to the family Vespertilionidae, - the only family whose distribution reaches relatively far north. The bats must have entered America long ago (if they originated in the Old World, as suggested by Darlington, 1957, and Matthew, 1915) to succeed in evolving as much as six endemic families there.

Primates: While in America the G/F index is higher than $\mathrm{S} / \mathrm{G}$, the situation in the Old World is reversed; it is a sort of anomaly since - as it has been already mentioned earlier - the latter index is usually lower than the G/F one. It is striking that both ratios are almost identical for the whole World (two last columns in Table 7). The families of this order are particularly poor in species; only Sirenia Perissodactyla, and Cetacea have less species (Table 8).

Carnivora: There is particularly large number of common taxa. It is caused in part by inclusion of a former order Pinnipedia whose representatives, as marine animals, are widely distributed. It is perhaps associated with their adaptation to life in cold climates, and hence with their ranges reaching far north. Therefore they did not have difficulties in crossing former Berlingia. In the Old World they show a high value of $\mathrm{G} / \mathrm{F}$ (third only to Rodentia and Insectivora) while the $\mathrm{S} / \mathrm{G}$ ratio is low (Table 7). It is a striking difference. Such disproportions occur when the whole World is considered, and also among the common taxa. Particularly suprising is the fact that this large order does not have endemic families in America.

Cetacea and Sirenia: Both orders have rather low S/G ratios (Table 7), similar ecology, and large body sizes. It is not, however, known whether any cause-and-effect relationships occur. Artiodactyla, for example, have also such low ratios.

Perissodactyla: They now occur mainly in the Old World, and the ratios concerned are rather low. The S/G ratio is higher than G/F. The number of species per family is among the lowest, higher only than that of Sirenia (Table 8).

Artiodactyla: As for such large mammals they are represented by relatively large numbers of species and genera. In both Worlds large differences between $\mathrm{G} / \mathrm{F}$ and $\mathrm{S} / \mathrm{G}$ ratios have been noted. As regards 
the number of taxa, the Old World prevails mainly because of large family Bovidae. A high proportion of common taxa (Table 6) ean be explained on similar grounds as in Carnivora. In America Artiodactyla have very high $\mathrm{G} / \mathrm{F}$ ratio (second only to Chiroptera) although the S/G value is the lowest. In the Old World, however, in spite of the fact that the G/F ratio is even higher than in America, it still remains lower than those in Rodentia, Insectivora, and Carnivora (Table 7).

Rodentia: The G/F ratio in the Old World is the highest of all ratios given in Table 7. Moreover, in this part of the World the difference between the G/F and S/G ratios is particularly large while in America remains moderate. It is the only order in which the number of families is higher in America than in the Old World. The $S / F$ ratio in the Old World is much higher than that in America (Table 8).

Table 9

\begin{tabular}{lcc}
$\begin{array}{l}\text { Comparison of taxon numbers in Chi- } \\
\text { roptera and Rodentia in New and Old } \\
\text { World (common taxons excluded). } \\
\text { Wom }\end{array}$ \\
\hline Taxon & New World & Old World \\
\hline Chiroptera & & \\
Families & 6 & 8 \\
Genera & 75 & 93 \\
Species & 278 & 640 \\
Rodentia & & \\
Families & 17 & 13 \\
Genera & 141 & 245 \\
Species & 771 & 946 \\
\hline
\end{tabular}

Lagomorpha: In America they have the highest S/G ratio among all these given in Table 7 .

It is tempting to study the numerical relationships within Chiroptera and Rodentia of the two parts of the World. These two orders are richest in species, and stand out in respect to both diversity of niches occupied and extent of their wide distribution. However, they differ much in their biology. Rodentia are unique in having more families in America than in the Old World, although this latter region supports a larger number of genera and, by smaller margin, a larger number of species (Table 9). On the other hand, in Chiroptera, families and genera are slightly more numerous, and species are much more numerous in the Old World (Table 9).

In America the highest G/F ratios are found in Chiroptera, Artiodactyla, and Rodentia while the lowest one - in Marsupialia (Table 
7). When the $S / G$ ratios are considered the line-up is different: the highest values are noted in Lagomorpha, Insectivora, Marsupialia, and Rodentia. The lowest values of S/G ratio appear in Artiodactyla, $\mathrm{Ce}$ tacea and Primates. One of the causes of relatively low score of Chiroptera in this last comparison is the low value noted in-Neotropical family Phyllostomidae (2.9). As it has been already mentioned, this family has much more taxa than any other American family of bats.

In the Old World the highest values of $\mathrm{G} / \mathrm{F}$ ratio have been found in Rodentia, Insectivora, Carnivora, and Artiodactyla while the lowest among Perissodactyla, Primates, and Marsupialia. In S/G ratios Chiroptera and Insectivora lead the field. Apart from marine orders, low value of this ratio have been found in Artiodactyla, Carnivora, Marsupialia. In the Old World the $\mathrm{G} / \mathrm{F}$ ratios are often much higher than the $\mathrm{S} / \mathrm{G}$.

The highest values of $\mathrm{G} / \mathrm{F}$ ratios for the whole World are noted in Rodentia, Chiroptera, Artiodactyla and Insectivora. The lowest values are those in Sirenia (based on small numbers), Perissodactyla, Primates, Cetacea, and Marsupialia. In S/G ratios the highest values appeared in Insectivora, Chiroptera, Lagomorpha and Rodentia, the lowest in Sirenia, Cetacea, Artiodactyla and Carnivora (Table 7).

From comparisons of the $\mathrm{S} / \mathrm{F}$ proportions (Table 8) it can be seen that the Old World families usually have more species than those in America. A reverse relationship occur only in Marsupialia and Primates, although in the latter the difference is fairly small. Three orders with the highest $\mathrm{S} / \mathrm{F}$ values (Insectivora, Chiroptera, and Rodentia) are at the same positions in the whole World. They are also the orders that are richest in species, although in number of genera Insectivora rate sixth. Besides, these three orders include animals of the smallest body sizes among all mammals. Smaller body size, apart from allowing larger population size (Krzanowski, 1967) may also enable the species to occupy more ecological niches thus favouring evolutionary radiation and hence the emergence of new taxa.

All the orders except Primates show striking differences in the S/F proportions between America and the Old World (Table 8). The highest value of this difference has been found in Insectivora. In America, the highest proportions are noted in Chiroptera and Rodentia, the lowest - in Primates. In the Old World the corresponding high extremal values are observed in Insectivora, Chiroptera, and Rodentia; while such orders as Perissodactyla, Primates, and Marsupialia represent the opposite tendency. In all, America has higher values in two cases (Marsupialia and Primates), the Old World - in four (Insectivora, Chiroptera, Artiodactyla, Rodentia), while five orders are incomparable. In 
the World as a whole, the highest $\mathrm{S} / \mathrm{F}$ ratios are found in Insectivora, Chiroptera, and Rodentia, the lowest ones are noted in Sirenia, Perissodactyla, and Cetacea.

Often, the more numerous the order the higher its $\mathrm{G} / \mathrm{F}$ and $\mathrm{S} / \mathrm{G}$ ratios. In some cases these particularly numerous orders show large differences between the $\mathrm{S} / \mathrm{F}$ and $\mathrm{S} / \mathrm{G}$ values. It occurs, for example, in Insectivora of the Old World, Chiroptera of America, Carnivora of the Old World, Artiodactyla of the whole World and Rodentia of the Old World. These discrepancies cannot be, however, regarded as an accurate measure of domination as defined by Darlington (1957), as the most numerous order Rodentia, has, in the whole World, much smaller difference than Carnivora. On the other hand, such numerous order as Primates, again in the entire World, shows almost no difference (Table 7). These various complications and "inconsistencies" in the distributions of mammals have resulted from extremely high number of factors, as always stressed by Darlington (1957). Rather unsatisfactory knowledge in the field of the evolutionary history of mammals must be rated among more important factors affecting all biogeographical considerations. The picture of the recent mammalian fauna represent only the proverbial tip of the iceberg. This, in turn, partly implies the deficiencies of modern taxonomy. The knowledge of mammalian fauna of certain parts of the World is equally unsatisfactory and unevenly advanced. All these gaps inadvertently affect the interpretations discussed in the presented paper.

It is not clear, for instance, why the families of the Old World are usually richer in species than those in America (Table 8). Perhaps in the Old World the rate of evolution was faster because of fragmentation of continents that increased chances of genetic isolation and thus prompted speciation. However, some other facts (eg. simple comparison of number of species in both Worlds) seem to contradict this assumption. The Old World covers $68.8 \%$ World's surface (the Antarctica excluded). Moreover, when compared with America, the Old World is extremely fragmented. The Philippine Islands for example, include no less than 7107 islands, Indonesia - over 3000. Since the geographic barriers enhance speciation, and sometimes are even considered essential for this process (Szarski, 1976), the number of species in the Old World might be expected to exceed severalfold the corresponding figure in the New World. Actually, after exclusion of 97 common species, and inclusion of 20 species of Cetacea that are not common, the total figure for America stands at 1419 species compared with 2663 species of the Old World ie. the latter is inhabited by only $65.2 \%$ of the mammalian species of the World. The comparisons made for 11 com- 
mon orders are shown in Table 10 . The Old World is relatively rich in Artiodactyla, Perissodactyla, and Insectivora. Chiroptera occupy middle position. The percentages for Rodentia are lowest. Sirenia, for which data are scarce, have not been included. Although Dr. Pat Morris of the University of London, UK (personal communication) links the outcome of above comparisons with an overall better knowledge of

Table 10

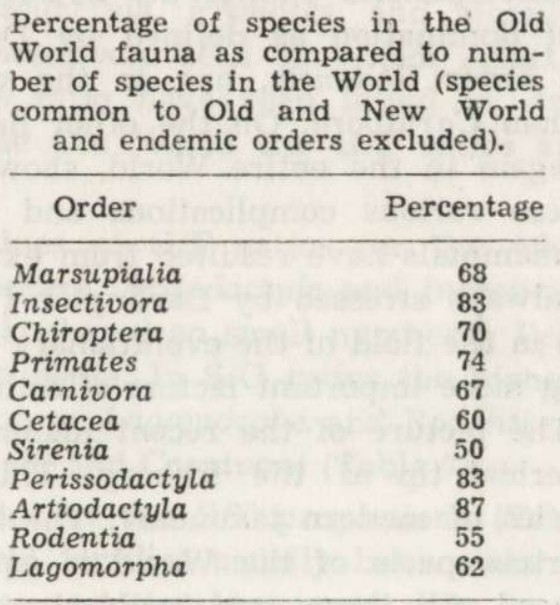

American fauna than those in other parts of the World, it seems to provide only a partial explanation. It should be noted that the Old World has eight endemic orders while America only one. Certainly, there is also an opposite approach possible: to assume that the number of species in the Old World is "normal" or "standard", but there will be a question to answer: why is America so rich in species?

It is realized that the calculations carried out in this study cover only the relationships most basic to the problem. The number of conclusions is also far from complete.

It should be very fruitful to carry out similar calculations for other classes of vertebrates and invertebrates, and to compare them with the results presented here. Such study may seem indispensable but, apart from birds, the lists of species necessary for it do not simple exist.

Acknowledgements: I am greatly indebted to Professor Z. Pucek (Mammals Research Institute, Białowieża) for his comments, and great effort put into the shaping of the paper. I would also like to thank Dr. H. Glab (Dept. of Anthropology, Jagiellonian University, Cracow) for his help in bibliographical research, and for lending literature on early human colonization of America. My thanks have to be extended to Dr. R. Tertil (Dept. of Animal Ecology, Jagiellonian University, Cracov) for translating the text into English). 


\section{REFERENCES}

1. Darlington, P. J., Jr., 1957: Zoogeography. VII-XI+1-675. J. Wiley \& Sons, New York.

2. Hall, E. R., 1981: The mammals of North America. 2nd ed., 2 vols., $X V+1-$ $-1175+1-90$. J. Wiley \& Sons, New York.

3. Honacki, J. H., Kinman K. E. \& Koeppl J. W. (eds.), 1982: Mammal species of the World. VI-IX+1-694. Allen Press, Lawrence.

4. Hopkins, D. M., Matthews, J. V. Jr., Schweger Ch. E. \& Young S. B. (eds.), 1982: Paleoecology of Beringia. 1-489. Academic Press, New York \& London.

5. Jepsen, G. L., 1966: Early Eocene bat from Wyoming. Science, 154: 1333-1338.

6. Kennedy, G. E., 1975: Early man in the New World. Nature, 255: 274-275.

7. Krzanowski, A., 1967: The magnitude of islands and the size of bats. Acta Zool. Cracov., 12: 281-348.

8. Matthew, W. D., 1915: Climate and evolution. Ann. New York. Acad. Sci., 24: $171-328$.

9. McCoy, E. D. \& Connor E. F., 1980: Longitudinal gradients in the species diversity of North American mammals. Evolution, 34: 193-203.

10. Russell, D. E., Louis P. \& Savage D. E., 1973: Chiroptera and Dermoptera of the French early Eocene. Univ. Calif. Publ. Geol. Sci., 95: 1-57.

11. Ryberg, O., 1947: Studies on bats and bat parasites. VII-XVI+1-330. Svensk Natur, Stockholm.

12. Szarski, H., 1976: Mechanizmy ewolucji. 1-220. Ossolineum, Wrocław.

13. Wilson, J. W., III; 1974: Analytical zoogeography of North American mammals. Evolution, 28: 124-140.

Accepted, April 3, 1986.

\section{Adam KRZANOWSKI}

POROWNANIE LICZBY TAKSONOW WSPOECZESNYCH SSAKOW W NOWYM I STARYM SWIECIE

Streszczenie

$\mathrm{Na}$ podstawie dzieła Honacki et al. (1982) badano liczby taksonów ssaków (Mammalia) w Ameryce i w Starym Swiecie. Badano głównie liczby rodzajów liczby rodzin (G/F) i liczby gatunków/ liczby rodzajów (S/G), w mniejszym zaś stopniu liczby rodzin /liczby rzędów (F/O) i liczby gatunków/ liczby rodzin (S/F). Badano niemal wyłącznie 11 rzędów mających przedstawicieli w obu częściach świata. Wyróżniano kategorie taksonów endemicznych, taksony wspólne dla Nowego i Starego Swiata oraz lączono w sumaryczne kategorie taksony endemiczne z wspólnymi.

Okazało się, że rzędy endemiczne (45\% wszystkich rzędów ssaków) liczą tylko $2 \%$ wszystkich gatunków (Tabela 2). Współczynnik S/G jest wyraźnie niższy od współczynnika G/F i współczynnika F/O (Tabela 3). Szczególnie wysoki procent taksonów wspólnych wykazują rzędy morskie i Carnivora, ostatnie nawet po odrzuceniu „Pinnipedia” (Tabele 1, 5, 6). Szczególnie wysokie współczynniki wy- 
kazują przede wszystkim rzędy liczne, których przedstawiciele mają również drobne wymiary ciała. Natomiast niskie współczynniki mają głównie rzędy ssaków morskich, których przedstawiciele mają znaczne wymiary ciała (Tabela 7). Nietoperze nie wyróżniają się pod względem tych współczynników od ịnnych drobnych ssaków. W proporcjach S/F uderzają znaczne różnice między Ameryką, a Starym Swiatem (Tabela 8). Największe są one u Insectivora, zaś małe różnice wykazują tylko Primates. Biorąc pod uwagę cały Swiat, najwyższe liczby w tych proporcjach wykazują Insectivora, Chiroptera i Rodentia, najniższe zaś, Sirenia, Perissodactyla i Cetacea.

$\mathrm{Na}$ ogbł, rodziny Starego Swiata są bogatsze w gatunki, niż amerykańskie. Stary Swiat, biorąc pod uwagę jego niezwykłe rozczłonkowanie posiada stosunkowo mało gatunków saków, zwłaszcza zaskakująco nieliczne są w nim Rodentia. Ameryka jest stosunkowo bogata w ssaki, najbardziej w Rodentia (Tabela 10). 